\title{
Hydrologická bilance a disponibilní vodní zdroje v České republice v době hydrologického sucha
}

\section{ADAM VIZINA, RADEK VLNAS, MARTIN HANEL, LADISLAV KAŠPÁREK, EVA MELIŠOVÁ, ADAM BERAN, ROMAN KOŽíN, FILIP STRNAD}

Klíčová slova: hydrologická bilance - vodohospodářská bilance - sucho - zdroje vody

\section{SOUHRN}

Článek se zabývá hodnocením hydrologické bilance na celém území České republiky, které bylo rozděleno do 133 mezipovodí za období 1981-2015 v měsičc ním časovém kroku. Pro ověření, jak se suchá období chovala, byl použit model hydrologické bilance Bilan, pomocí kterého byly tyto epizody za posledních 35 let vyhodnoceny, a to jak z pohledu jednotlivých zásob vody (sníh, půda, podzemní vody), tak podle jednotlivých toků vody (srážky, evapotranspirace, infiltrace, odtok). Článek dále seznamuje s výsledky disponibilní vody za normálních podmínek a při pětiletém a desetiletém suchu ve dvou variantách. První se zabývá vyhodnocením zdrojové oblasti, ve druhé je vyhodnocení pomocí zjednodušeného modelu vodohospodářské bilance WATERES.

\section{ÚVOD}

Sucho, které postihlo Českou republiku v roce 2015, bylo mimořádné a celospolečensky široce diskutované. Tato suchá epizoda se postupně projevila výskytem všech typů sucha (meteorologické, zemědělské, hydrologické) a širokým spektrem jeho dopadů (sucho socioekonomické). Tato suchá epizoda je často zdůvodněna tím, že povrchová vrstva povodí má nízkou retenční kapacitu. Dalším důvodem byly sněhově podprůměrné zimy v letech 2014 a 2015 a srážkově podprůměrný rok 2015. Cílem úkolu tedy je vyhodnocení těchto faktorů z časoprostorového pohledu na celém území České republiky.

\section{METODIKA}

Hydrologická bilance se stanovuje pro povodí či určité území. Rekapituluje vstupy (srážky, prítok, zásoby) a výstupy (výpar, odtok, úbytek zásob vody) do hydrologického systému. Pro hodnocení hydrologické bilance byl použit model Bilan, který je vyvíjen více jak 15 let v oddělení hydrologie Výzkumného ústavu vodohospodářského T. G. Masaryka. Model počítá v denním či měsičním časovém kroku chronologickou hydrologickou bilanci povodí či území. Vyjadřuje základní bilanční vztahy na povrchu povodí v zóně aerace, do níž je zahrnut i vegetační kryt povodí, a v zóně podzemní vody. Jako ukazatel bilance energie, která hydrologickou bilanci významně ovlivňuje, je použita teplota vzduchu. Výpočtem se modeluje potenciální evapotranspirace pomocí metody [1, 2], územní výpar, infiltrace do zóny aerace, průsak touto zónou, zásoba vody ve sněhu, zásoba vody v půdě a zásoba podzemní vody. Odtok je modelován jako součet tří složek: dvě složky prímého odtoku (zahrnující i hypodermický odtok) a základní odtok (např. [3]). Vstupem do modelu jsou: (i) srážkové úhrny [mm], (ii) průměrné teploty, (iii) průměrná vlhkost vzduchu [\%], (iv) pozorované odtokové výšky [mm], (v) užívání vody [mm/měsíc], (vi) potenciální evapotranspirace $[\mathrm{mm}]$.

Schéma modelu Bilan je zobrazeno na obr. 1 pro modelování přirozených (neovlivněných) průtoků, schéma propojeného modelu Bilan, který zahrnuje užívání vody, tzn. hodnoty o podzemních i povrchových odběrech a vypouštění je uvedeno v publikaci Vizina a kol. [3]. Další výpočty byly provedeny v prostředí R [4] a byly použity především balíky Bilan [5] a WATERES [6]. Pro hodnocení propagace sucha se využívají indikátory popsané například v [7].

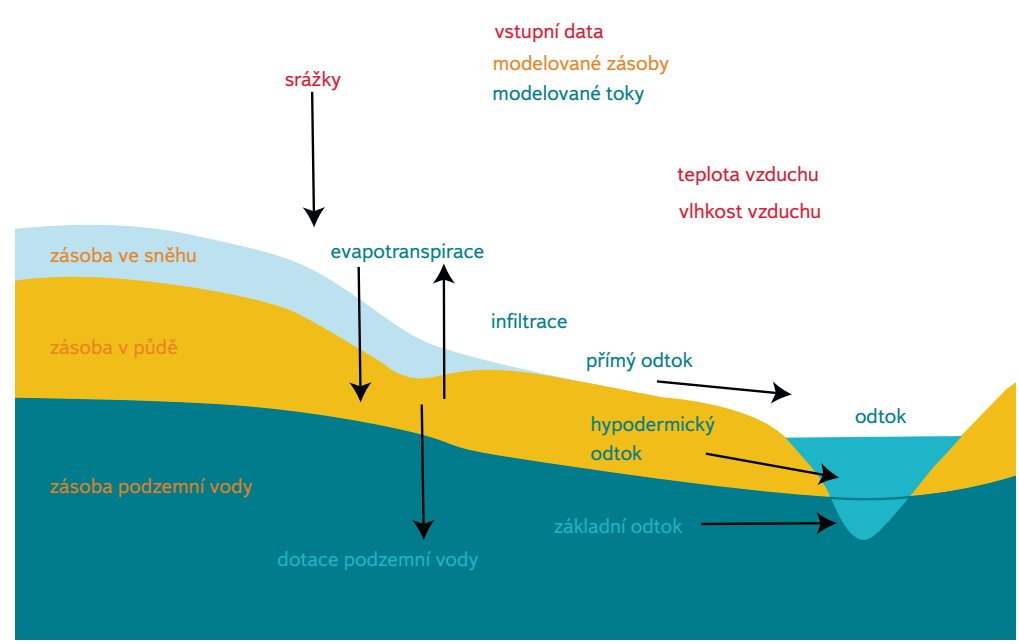

Obr. 1. Schéma modelu Bilan

Fig. 1. Scheme of model Bilan

Hydrologická bilance byla modelována na sadě 133 mezipovodí, která pokrývají území celé České republiky, v měsíčním časovém kroku za období 1980-2015. Rozmístění jednotlivých mezipovodí je možné vidět na obr. 2. Červená číla jsou identifikátory jednotlivých mezipovodí, které převážně vycházejí z databázových čísel vodoměrných stanic, které se na daném území nacházejí, případně jsou závěrným profilem daného mezipovodí. 


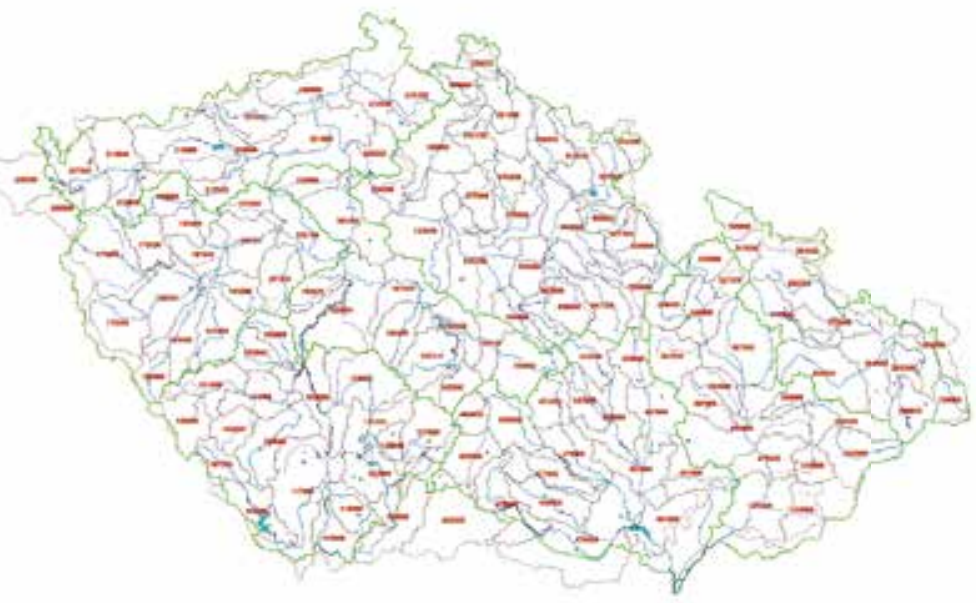

Obr. 2. Mapa řešené oblasti s jednotlivými mezipovodími Fig. 2. Study area with intercatchments

\section{VÝSLEDKY A DISKUSE}

Průměrný roční odtok za období 1981-2015 je zobrazen na obr. 3 (nahoře). Lze vidět, že odtokové výšky se pro jednotlivá mezipovodí pohybují od desítek mm v suchých oblastech až po cca $700 \mathrm{~mm}$ za rok pro mezipovodí nacházející se $\checkmark$ oblastech horských. Průměrný odtokový součinitel za zmíněné období nám ukazuje obr. 3 (dole). Jedná se o poměr odtokové výšky ke srážkovému úhrnu. Na základě tohoto součinitele mủžeme jednoduše odvodit, že v tradičních deficitních oblastech se nacházejí i povodí s nízkým odtokovým součinitelem (tzn., že v těchto oblastech je malé množství vody, které je možné využít).

Sumarizované hodnocení bilance za období 1981-2015 je zobrazeno na následujících grafech. Jedná se o měsíční boxploty pro všechna řešená mezipovodí (133). Obarvení jednotlivých boxplotů je dáno průměrnou měsiční hodnotou $\vee$ daném roce. Hodnoty Ize určit pomocí legendy, která je uvedena $\checkmark$ pravé části grafu. Na obr. 4 jsou uvedeny měsiční hodnoty odtokových výšek (značeno 1-12, v pořadí leden-prosinec). Jak již bylo zmíněno, obarvení jednotlivých boxplotů nám udává průměrnou roční hodnotu. V tomto prípadě to znamená, že červená barva ukazuje roky málo vodné a směrem k barvě modré se jedná o roky vodnatější. Na obr. 4 můžeme pozorovat, že roky 2014 a 2015 patřily k těm nejméně vodným (spolu s roky na počátku devadesátých let). Modrá čára udává trend pro jednotlivé měsíce. Trendová analýza byla provedena pomocí metody GAM-Generalized Additive Models [8]. Trend pro jednotlivé měsíce nebyl dále statisticky testován. Na grafu můžeme pozorovat, že odtokové výšky $\checkmark$ letních měsících roku 2015 byly opravdu extrémní a $v$ pozorované řadě se v jiném období nevyskytovaly.

\section{SITUACE V LETECH 2003 A 2015}

Na obr. 5 jsou zobrazeny absolutní odtokové výšky v jednotlivých měsících v milimetrech pro jednotlivá mezipovodí v roce 2015. Lze pozorovat, že mapy maji tendenci mít červenou barvu (v průměrném roce je mapa spíše žluto-zelená), což značí výrazně nízké odtoky, které se nacházejí téměř na celém území České republiky, a to predevším v letních a prvních podzimních měsících.

Pro ilustraci, jaké byly odtokové výšky, relativní změny odtoku, hodnoty evapotranspirace a absolutní změny $v$ zásobě vody ve sněhu v roce 2003 a 2015, se prìkládá obr. 6. V levém sloupci je uveden rok 2003, v pravém potom rok 2015.
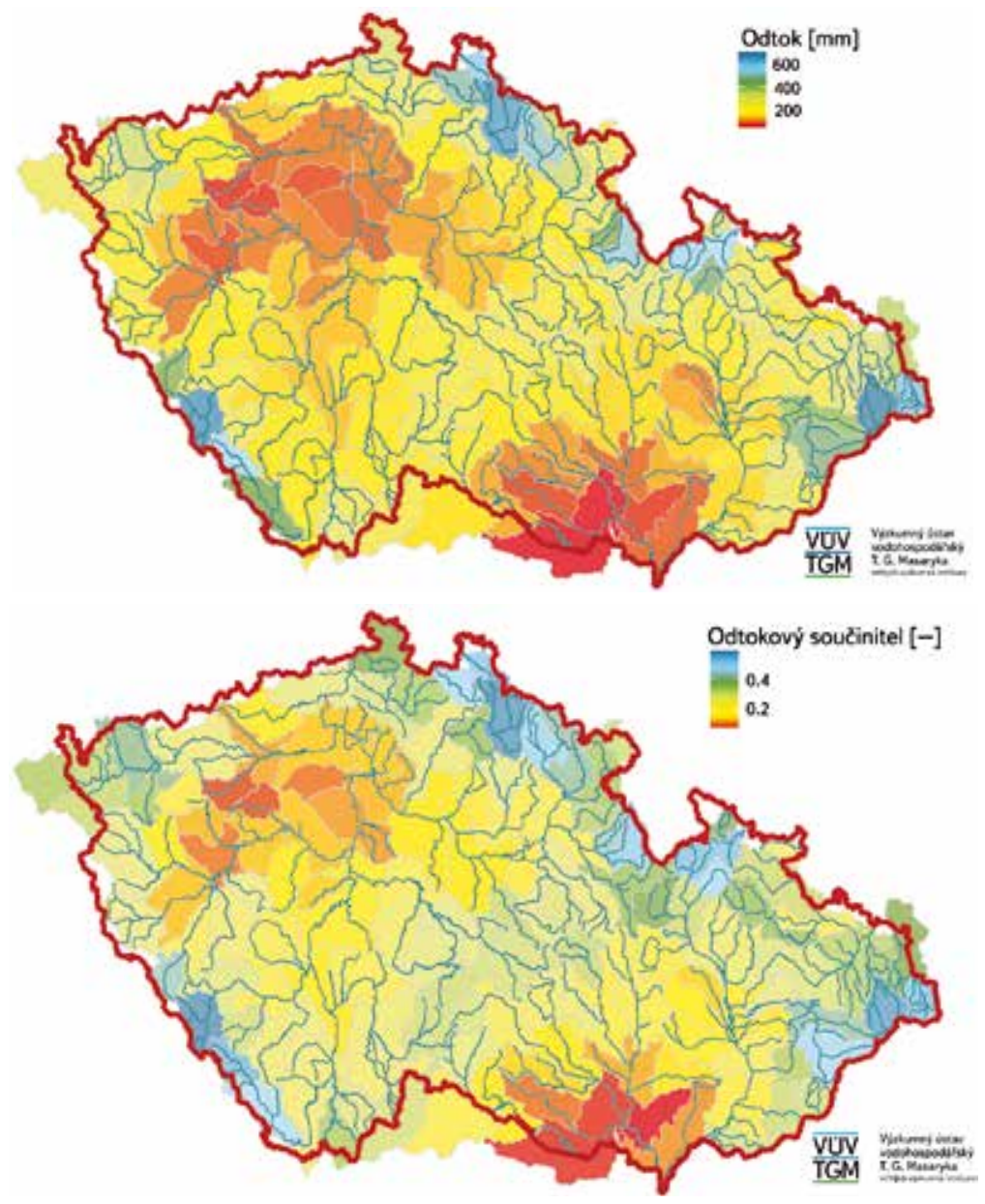

Obr. 3. Průměrný roční odtok v mm (nahoře) a odtokový součinitel (dole) za období 1981-2015

Fig. 3. Mean annual runoff in mm (above) and runoff coeficient (down) for the period $1981-2015$

Absolutní hodnoty odtokových výšek jsou zobrazeny v prvním řádku. Na obrázku v druhém řádku je možné pozorovat, že průměrné roční odtokové výšky za tyto roky dosahují rádově 30-70\% průměru za období 1981-2015 (bílá barva reprezentuje nezměněný stav, žlutá pokles a modrá nárůst). Ve třetím rádku jsou hodnoty evapotranspirace, které $v$ těchto letech dosahovaly relativně nízkých hodnot, což je dáno především tím, že nebyla disponibilní voda v půdě, která by evapotranspirovala. Analogicky je zobrazena relativní změna zásoby vody ve sněhu $v$ mm (čtvrtý rádek). Zásoba vody ve sněhu má většinou velký vliv na odtokové poměry v celém roce. $V$ roce 2015 oproti průměrným podmínkám za období 1981-2015 Ize pozorovat výrazný pokles zásoby, což je jedním z hlavních důvodů nedostatku vody v roce 2015 v kombinaci s výrazně podprůměrnou zimou v roce 2014. Zásoba vody ve sněhu má také velký vliv na doplňování zásob podzemních vod, což se projevilo poté především v roce 2016, kdy zásoby poklesly ( $v$ České republice existuje také cyklicita v zásobách podzemních vod). Výstupy pro změny odtoku, průměrné odtoky, aktuální evapotranspirace a změny zásoby vody pro jednotlivé roky jsou dostupné na webu www.suchovkrajine.cz. 

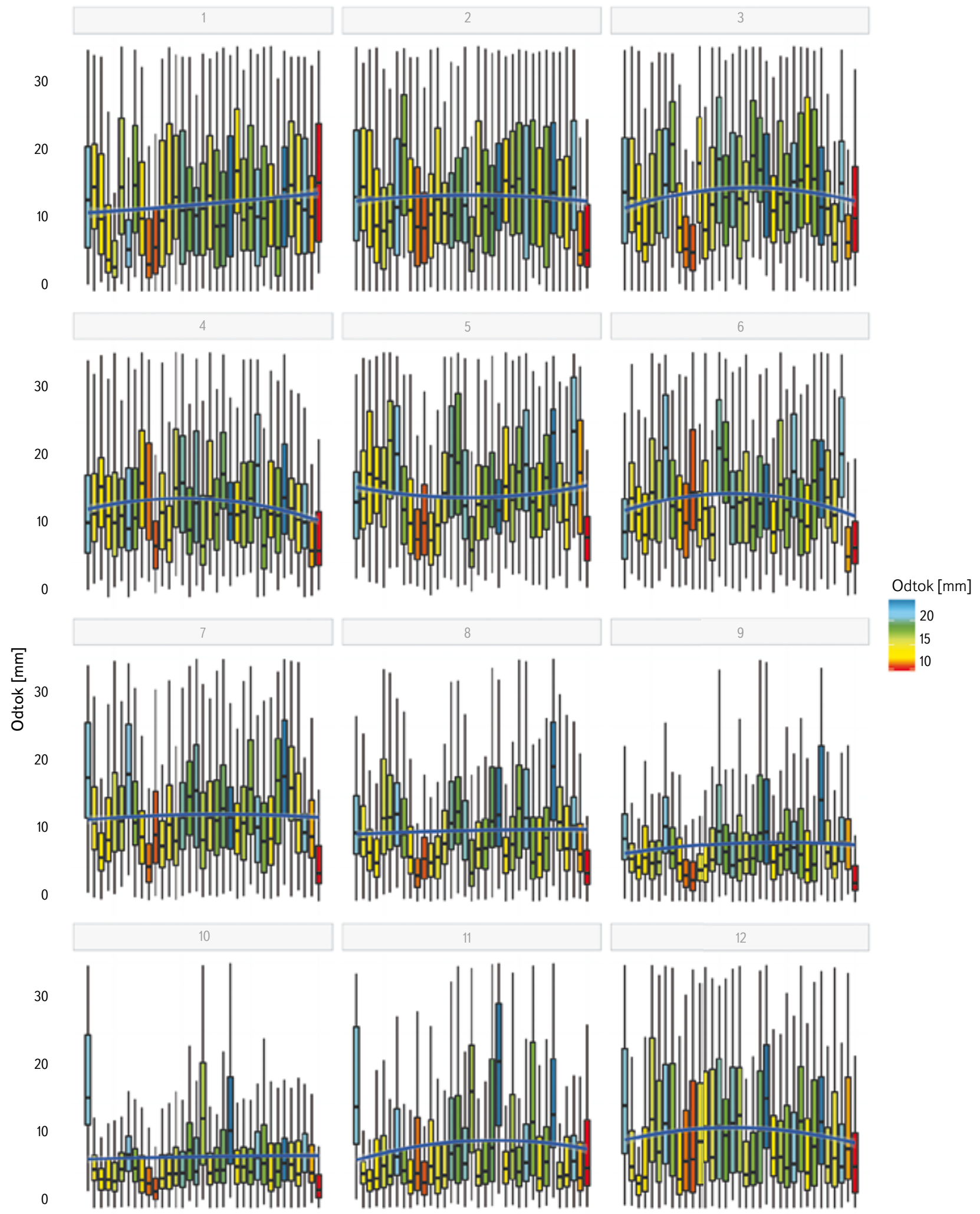

$\begin{array}{ccccccccccc}1980 \quad 1990 \quad 2000 & 2010 \quad 1980 & 1990 & 2000 & 2010 & 1980 & 1990 & 2000 & 2010 \\ & \text { Rok } & c\end{array}$

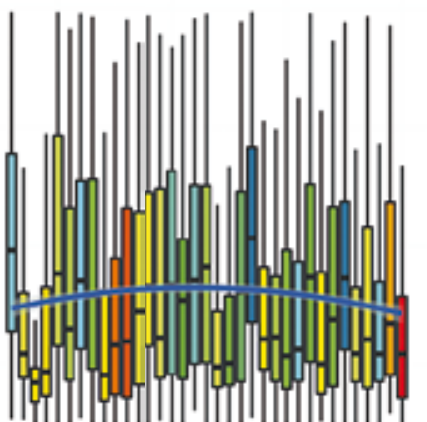




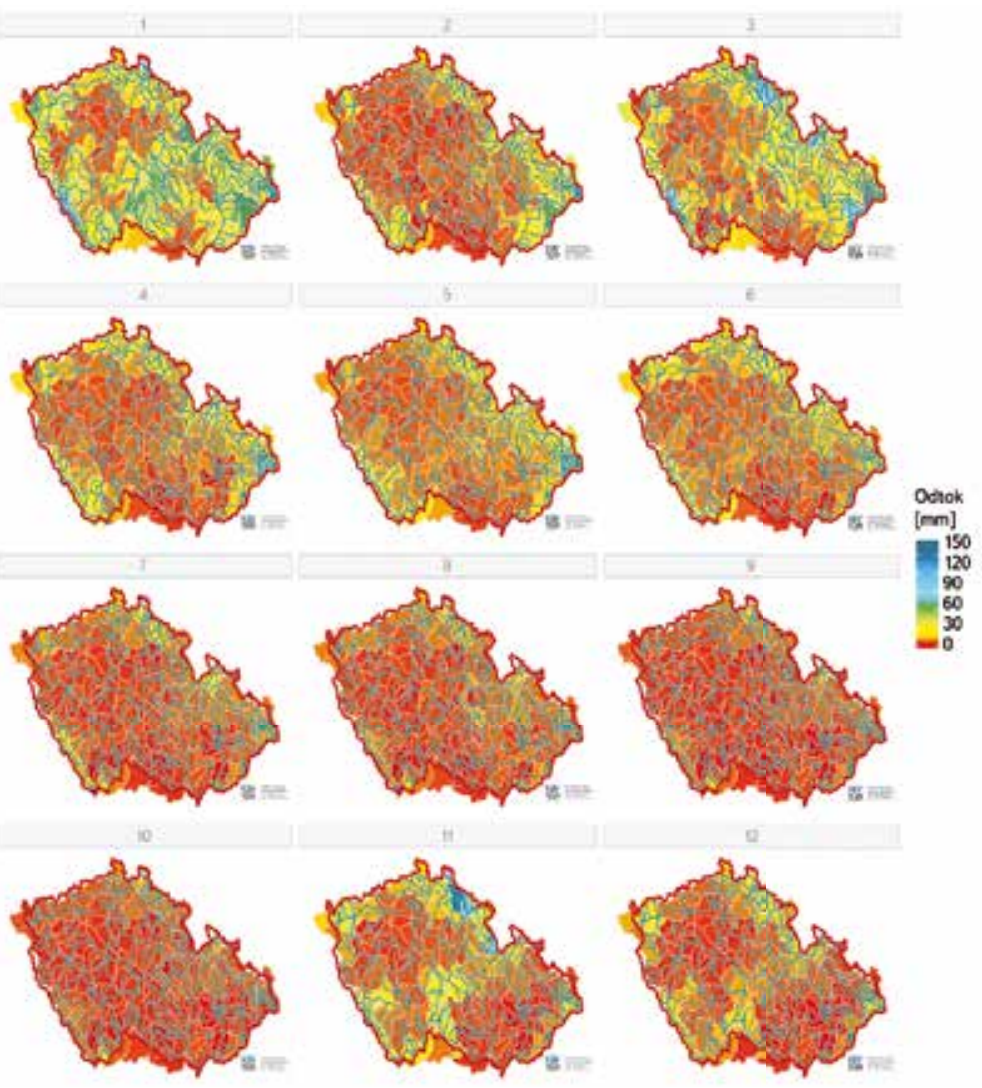

Obr. 5. Absolutní odtokové výšky v roce 2015 v jednotlivých měsících (značeno 1-12, leden-prosinec)

Fig. 5. Absolute runoff heights in 2015 for each months (ranked 1-12, January-December)

\section{DISPONIBILNÍ VODNÍ ZDROJE}

Disponibilní vodní zdroje modelované modelem WATERES [6] jsou zobrazeny na následujících obrázcích ve variantním výpočtu, kdy se uvažovalo, že jednotlivá povodí fungují samostatně (varianta MEZI) a pro zapojení jednotlivých povodí do vodohospodárské soustavy (varianta SOUST). Na obr. 7 jsou průměrné disponibilní zdroje (mediány) pro variantu MEZI. V této variantě se disponibilní vodní zdroje (za období 1981-2015) pro jednotlivá mezipovodí pohybují okolo $4 \mathrm{~m}^{3} . \mathrm{s}^{-1}$. Logicky vyšší hodnoty se vyskytují na horských a podhorských povodí a naopak nižší hodnoty se vyskytují v nižinách. Zajímavé však je, jak dostupnost vodních zdrojů klesá pro pětileté sucho a zejména pro sucho desetileté, kdy i pro současné podmínky jsou hodnoty téměř nulové. Výjimkou je mezipovodí v Praze, kde je velký vliv vypouštění z ČOV. To s sebou však samož̌ejmě nese zhoršenou kvalitu vody (problematika je popsána v rámci jiného úkolu na stránkách www.suchovkrajine.cz).

Pro variantu SOUST a současné podmínky jsou dostupné vodní zdroje zobrazeny na obr. 8. Pro prüměrné podmínky hodnoty dosahuje Labe na hranicích ČR hodnot téměř $200 \mathrm{~m}^{3} . \mathrm{s}^{-1}$. Pro pětileté sucho tato hodnota klesá na třetinu a u desetiletého sucha přibližně na pětinu. Obdobné snížení je možné pozorovat pro období sucha i na ostatních tocích.

Vliv vodních nádrží na hydrologické sucho můžeme pozorovat na obr. 9, kde jsou zaznamenány denní průtoky na Labi v Děčíně za období 1880-2015. Barvy označují jednotlivá sucha, která jsou dána M-denními vodami (300, 330, 355 a 364) a silná červená čára vyjadřuje celkový retenční prostor v celém povodí s vyznačením uvedení do provozu nejvýznamnějších nádrží a jejich objemem.
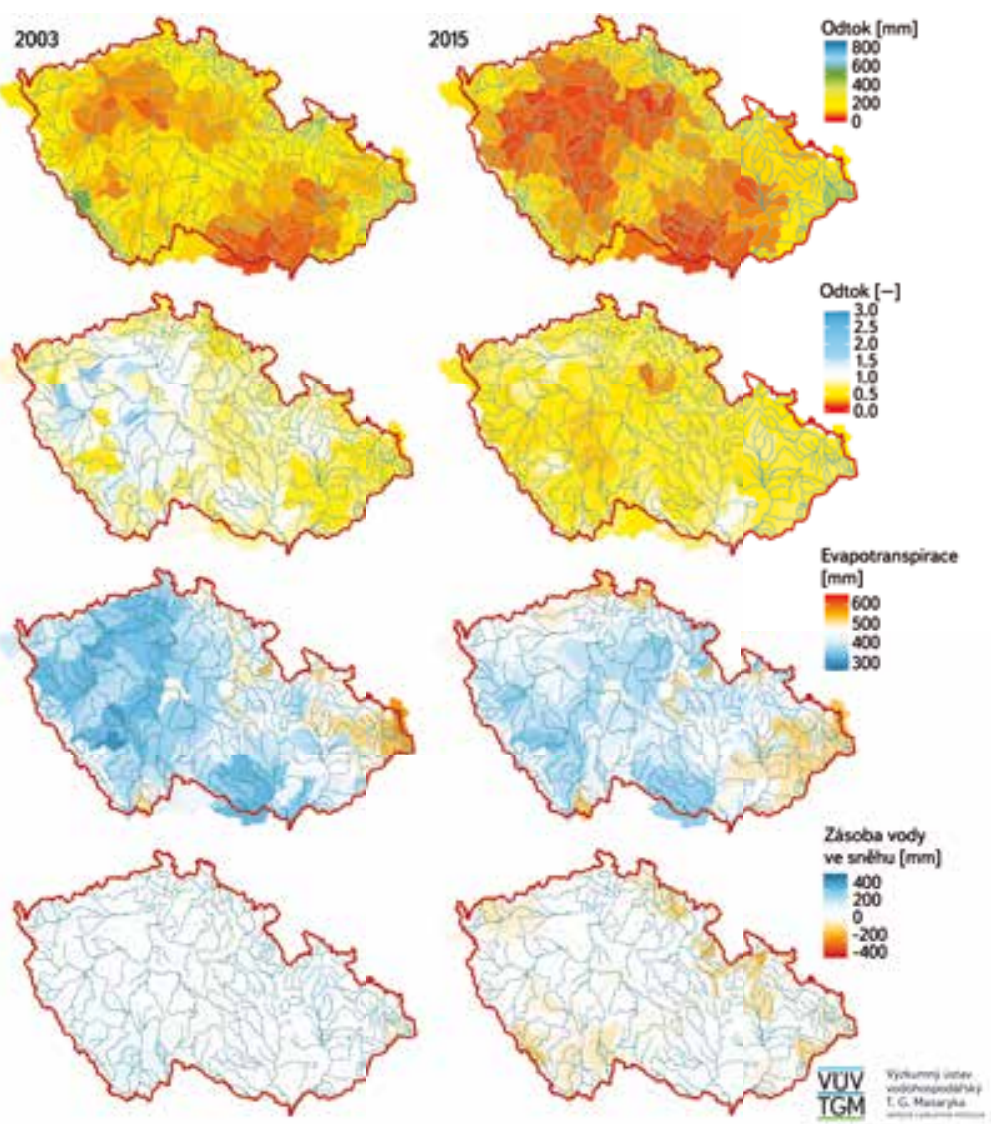

Obr. 6. Absolutní hodnoty odtokových výšek v mm, relativní změna odtoku za rok 2003, 2015 k referenčnímu období 1981-2015, hodnoty evapotranspirace $v$ mm a změna zásoby vody ve sněhu k období 1981-2015 v mm

Fig. 6. Absolutes values of runoff heights in $\mathrm{mm}$, relative change of runoff in year 2003, 2015 vs reference period 1981-2015, evapotranspiration in $\mathrm{mm}$ and changes in water storages at snow vs reference period 1981-2015 in mm

\section{ZÁVĚR}

Byla zpracována hydrologická bilance na celém území České republiky na souboru 133 mezipovodí pro současné a výhledové podmínky. Dále byly zpracovány disponibilní vodní zdroje $v$ jednotlivých letech a výhledech ke konci 21. století. Byla provedena trendová analýza jednotlivých veličin podle MannKendall testu. Výsledky byly zpracovány do mapových podkladů, které jsou k dispozici ve větším měřítku na webovém portále www.suchovkrajine.cz. Na základě zjištěných poznatků zde bodově uvádíme obecné závěry a doporučení:

1. vyhodnotit hydrologickou a vodohospodářskou bilanci v denním kroku na území ČR,

2. zpracovat hydrologickou bilanci pro jednotlivé vodní útvary,

3. vytvoření propojeného modelu hodnotícího hydrologickou, vodohospodářskou bilanci v on-line módu,

4. zpracování dlouhodobých syntetických r̆ad pro vyhodnocení hydrologické bilance, u které by se daly stanovit dlouhodobé doby opakování. 

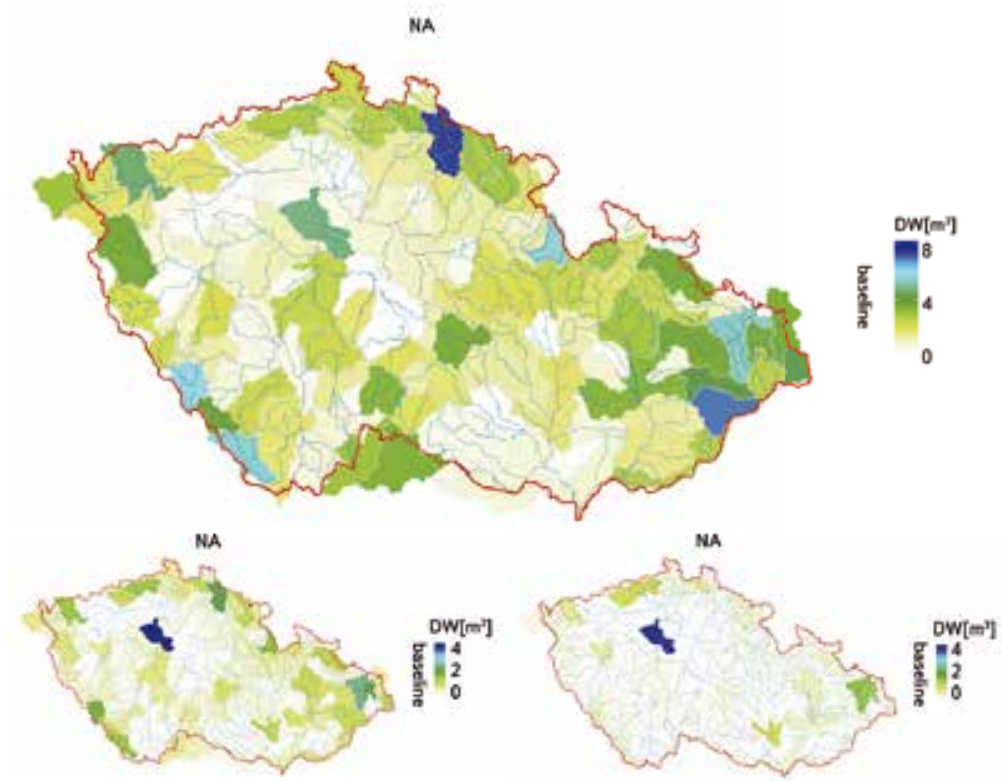

Obr. 7. Disponibilní vodní zdroje pro variantu MEZI (nahoře - medián, vlevo - pětileté sucho, vpravo - desetileté sucho)

Fig. 7. Disponible water sources for variant MEZI (above - median, left - 5 years drought, right - 10 years drought)
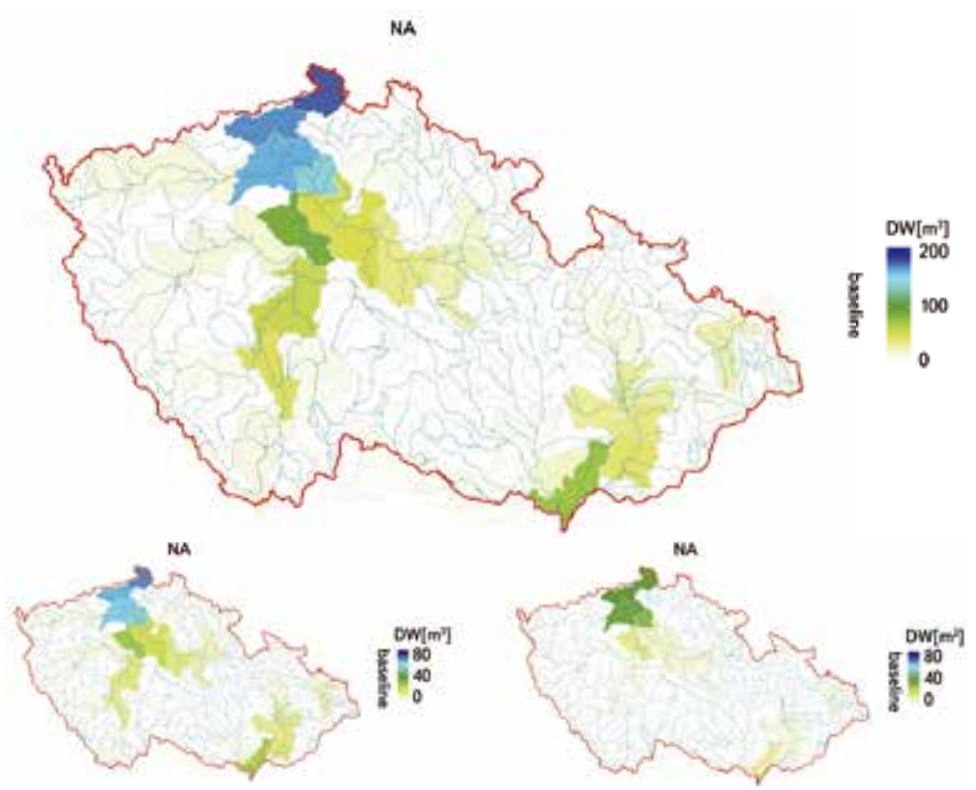

Obr. 8. Disponibilní vodní zdroje pro variantu SOUST (nahoře - medián, vlevo - pětileté sucho, vpravo - desetileté sucho)

Fig. 8. Disponible water sources for variant SOUST (above - median, left -5 years drought, right - 10 years drought)

Výsledky byly využity pro návrh Koncepce ochrany před následky sucha pro území České republiky. V rámci řešení byly identifikovány následující nejistoty:

1. neexistence vybraných prostorově distribuovaných hydrologických podkladů $\checkmark$ potřebné podrobnosti (minimální a maximální odtoky, charakteristiky variability odtoku, vybrané kvantily rozdělení odtoku, charakteristiky základního odtoku apod.) pro kalibraci hydrologického modelu BILAN na mezipovodí;

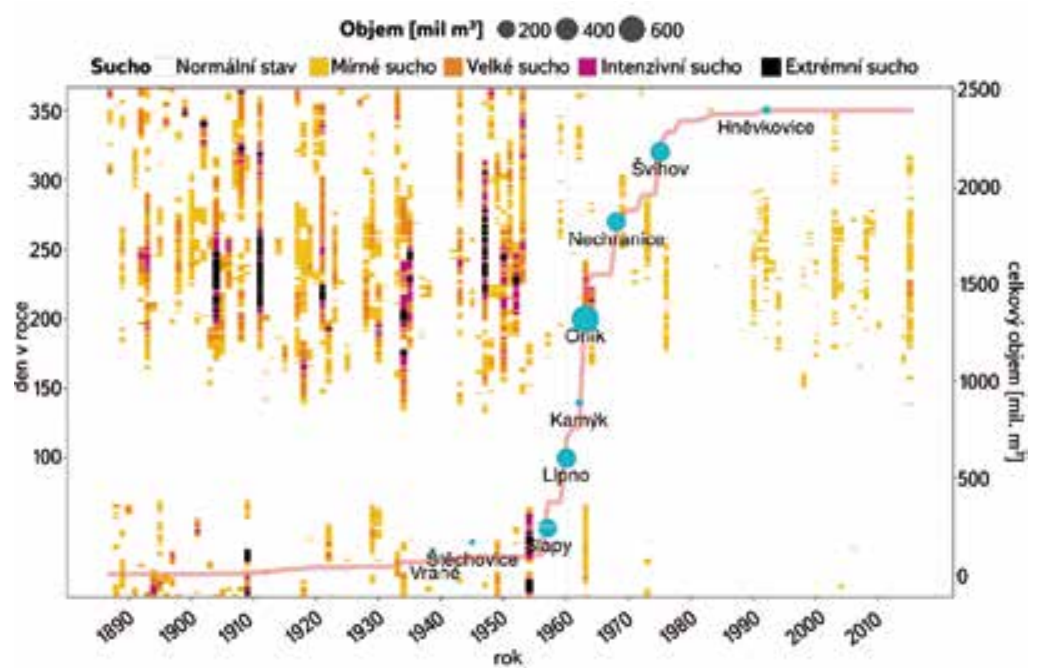

Obr. 9. Výskyt hydrologického sucha na Labi v historické časové řadě s uvážením vlivu Vltavské kaskády

Fig. 9. The occurrence of hydrological drought on the Elbe in historical time series considering the influence of the Vltava cascade

2. malá podrobnost řešení, která hodnotí pouze velké územní celky, lokální problémy mohou zaniknout;

3. neexistence syntetických řad, podle kterých je možné simulovat delší doby opakování (tzn. kvantifikovat např́klad 100leté sucho).

\section{Poznámky}

1. V deskriptivní (popisné) statistice je boxplot neboli krabicový graf či krabicový diagram jeden ze způsobů grafické vizualizace numerických dat pomocí jejich kvartilů. Střední „krabicová“ část diagramu je shora ohraničena 3. kvartilem, zespodu 1. kvartilem a mezi nimi se nachází linie vymezující medián.

\section{Poděkování}

Přispěvek vznikl v rámci úkolů rešených pro Ministerstvo životního prostředí České republiky. 


\section{Literatura}

[1] BERAN, A., HORÁČEK, S., HANEL, M. Zjednodušení metody výpočtu potenciální evapotranspirace v nové verzi modelu BILAN. VTEI, 2011, roč. 53, mimořádné číslo III, s. 15-18, přiloha Vodního hospodárstV.

[2] OUDIN, L., MOULIN, L., BENDJOUDI, H., RIBSTEIN, P. Estimating potential evapotranspiration without continuous daily data: possible errors and impact on water balance simulations. Hydrological Sciences Journal, 2010, vol. 55, No. 2, p. 209-222.

[3] VIZINA, A., HORÁČEK, S., HANEL, M. Nové možnosti modelu Bilan. VTEI, 2015, roč. 57, Č. 4-5.

[4] R Core Team. R: A language and environment for statistical computing. R Foundation for Statistical Computing, Vienna, Austria, 2015. Dostupné z: https://www.R-project.org/

[5] KAŠPÁREK, L., HANEL, M., HORÁČEK, S., MÁCA, P., VIZINA, A Bilan water balance model. R package version 2016-06-16, 2016.

[6] HORÁČEK, S., KOŽÍN, R. Characteristics and Simulations for Water Reservoirs. R package version 2015.8.9000, 2016

[7] VIZINA, A., HANEL, M., MELIŠOVÁ, E. Analýza propagace sucha pomocí generátoru počasí. Vodní hospodáŕství, 2014, roč. 56, č. 6, s. 5-11. ISSN 1211-0760.

[8] WOOD, S.N. Generalized Additive Models: An Introduction with R. Chapman and Hall/CRC., 2006.

\section{Autoři}

Ing. Adam Vizina, Ph.D.,

凶adam.vizina@vuv.cz

Ing. Radek VInas ${ }^{1,3}$

凶radek.vlnas@vuv.cz

doc. Ing. Martin Hanel, Ph.D.,

凶martin.hanel@vuv.cz

Ing. Ladislav Kašpárek, CSc. ${ }^{1}$

凶ladislav.kasparek@vuv.cz

Ing. Eva Melišová1,2

凶eva.melisova@vuv.cz

Ing. Adam Beran ${ }^{1,2}$

凶adam.beran@vuv.cz

Ing. Roman Kožín ${ }^{1,2}$

凶roman.kozin@vuv.cz

Ing. Filip Strnad²

凶strnadf@fzp.czu.cz

'Výzkumný ústav vodohospodářský T. G. Masaryka, v. v. i.

${ }^{2}$ Fakulta životního prostředí, Česká zemědělská univerzita v Praze

${ }^{3}$ Český hydrometeorologický ústav

Příspěvek prošel lektorským řízením.
HYDROLOGICAL BALANCE AND AVAILABLE WATER RESOURCE IN THE CZECH REPUBLIC DURING HYDROLOGICAL DROUGHT

\section{VIZINA, A. ${ }^{1,2}$; VLNAS, R. ${ }^{1,3}$; HANEL, M. ${ }^{1,2}$; KASPAREK, L.'; MELISOVA, E. ${ }^{1,2}$; BERAN, A. ${ }^{1,2}$; KOZIN, R., ${ }^{1,2}$; STRNAD, F. ${ }^{2}$}

${ }^{1}$ TGM Water Research Institute, p. r. i.

${ }^{2}$ Faculty of Environmental Sciences, Czech University of Life Sciences in Prague ${ }^{3}$ Czech Hydrometeorological Institute

Keywords: hydrology balance - water balance - drought - water sources

The article deals with the assessment of the hydrological balance in a monthly time step in the territory of the Czech Republic, which was divided into 133 sub-basins for the period 1981-2015. The hydrological balance model Bilan, which has been used to evaluate these episodes over the past 35 years, has been used to verify how the dry season has been propagated. The assessment includes individual water storages (snow, soil and groundwater) and individual water flows (precipitation, Evapotranspiration, infiltration and drainage). The article also introduces to the results of the available water under normal conditions and in 5 years and 10 years drought in two variants. The first one deal with the evaluation of the source area, the second is the evaluation using the simplified water balance model WATERES. 